\title{
KÓPHÁZI Andrea
}

\section{Több mint tankönyv - A munka világa ${ }^{1}$}

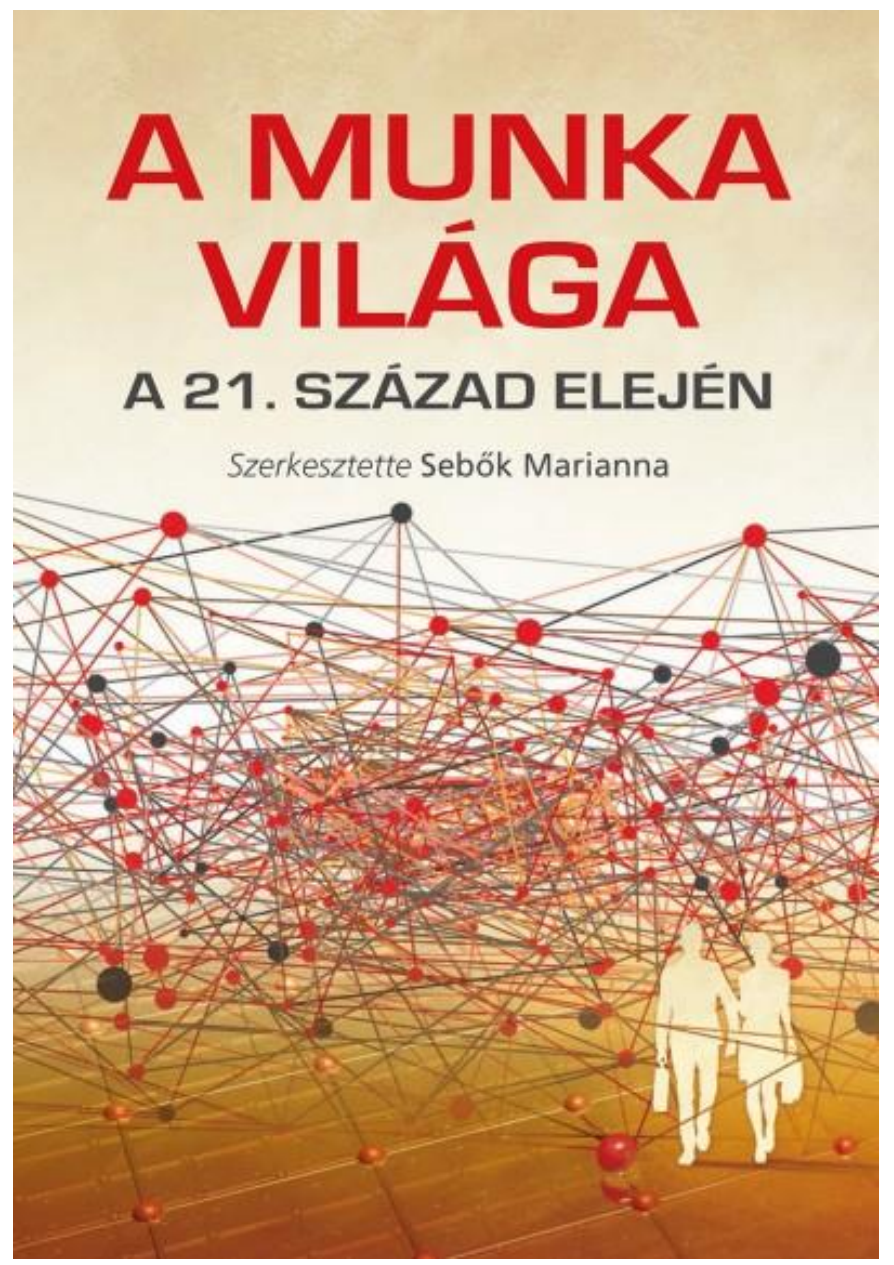

A foglalkoztatáspolitika minden országban kitüntetetten kezelt része az országok múködésének. A globális folyamatok a kérdést földrésznyi síkon is érdekeltté tették - a mai migrációs jelenség eredetében a foglalkoztatáspolitikának nagy része van. Hatásmechanizmusa régtől vizsgált és elemzett, megoldásán mindenütt munkálkodnak több-kevesebb felelősséggel és tudatossággal.

A hazai foglalkoztatáspolitika gazdag irodalommal, számos kutatással rendelkezik - legújabb évei pedig, köszönhetően a korábbi kormányzati innovációnak, sikerekkel jellemezhető. 2014-ben szakpolitikai elvek készültek a foglalkoztatáspolitikára. Példa erre „A 2014-2020 közötti időszak foglalkoztatáspolitikai célú fejlesztéseinek megalapozása. Szakpolitikai stratégia,2014.”2 Az elvek alapján a programok megvalósítása folyamatos - eddigi eredményei pedig kockázataival együtt közismertek. A foglalkoztatáspolitika jelentőségének tudatosítása, eszközrendszerének ismerete mindenképp a képzés szintereiben történő szükségesség. Ezért is üdvözlendő egy új kiadvány megjelenése, melynek alkotásában három egyetem vett részt. A Sebők Marianna szerkesztésében megjelent „A munka világa a 21 . század elején. Foglalkoztatáspolitikai es munkaerőpiaci kézikönyv"

\footnotetext{
${ }^{1}$ A munka világa a 21. század elején. Foglalkoztatáspolitikai es munkaerőpiaci kézikönyv. Szerkesztette: Sebők Marianna. SAXUM, Budapest. 2018. Alföldi Nyomda Zrt., Debrecen.

${ }^{2}$ https://ngmszakmaiteruletek.kormany.hu/download/a/4c/c0000/Fogl Strat 14-20 elfogadott.pdf (Letöltve: 2018. 05. 14.)
} 
sikeresen ötvözi a tankönyv és a nagyobb áttekintést nyújtó, a tudásokat kézikönyvként is közvetítő dokumentáció feladatát.

A kötet aktuális és stratégiai értékű, olyan időszakban született, amelyben a hagyományos munka mellett a munka körülményei dinamikus változás útjára léptek, a világgazdaság átrendezősége és a migrációs kényszerfolyamatok együttes befolyása egyre nagyobb terhet jelent, a globális munkapiac ellen ható nemzeti munkapiacok helyzete az eddigiektől eltérő teendőket kíván, hogy csak néhányat említsünk. A hazai foglalkoztatáspolitika újszerű megoldásokkal él - a kormányzati sikerpolitika a megoldási lehetőségek egyik metszetét adja. Az embert is érintő munkapiaci kutatásokban valamennyire is járatos olvasó tudja, hogy a kutatási technikák és a kutatási technikák mögött burkoltan meghúzódó elméleti előfeltevések révén mindig leplezetten határozzák meg a lényeget, s az empíria keretein belül maradva az eredmények - bármennyire is igazolja őket a spontán szociológia - sosem tények, hanem adatok. Ezért volt szükséges e kötetben az empíria előtt olyan elméleti összefoglalásra, amely a munka világának változásait illusztrálja az adott terjedelmi korlátok között.

A foglalkoztatáspolitika szükségszerűségét az ipari fejlődés 19. és 20. századi - helyenként minimális szinten is megjelenő - gyárrendszerű termelés és annak környezetre való befolyása emelte állandó társadalmi/gazdasági kérdéssé, melyekre az egyes világrészek, országok, régiók különbözőképpen igyekeztek válaszolni. A kötetben a tankönyvi igényt kielégítendő, e folyamatokra kellő ismereteket találunk. A szakmai nyelvezet jól érthető, a fejezetek egymásra épülése és kapcsolata az érthetőséget és belső kapcsolati rendszert jól tükrözi. A fejezetek célszerű rövidsége, célorientáltsága megkönnyíti a tanulhatóságot, a fejezetek rövid összegzései megerősítik a tanultakat. A fogalomtár a kötet értelmezési egységét szolgálja, megjegyezve, hogy a fogalmak átértékelődnek, nem lehet örökérvényű következtetésekre jutni egy olyan dinamikusan alakuló és ennek következtében változó területen, amilyen a munka, a munkapiac és a foglalkoztatáspolitika.

A rendszerelvűen, didaktikusan felépített tartalom a kérdéskör egészét átfogja. Részei: I. rész. 1. fejezet (Krisztián Béla) A munka világának jelentősége az ember és a társadalom kapcsolatában, 2. fejezet (Móré Mariann) A foglalkoztatáspolitika helye, szerepe a társadalomban. 3. fejezet (Móré Mariann) A foglalkoztatáspolitika tartalma, 4. fejezet (Szellő János) A Nemzetközi Munkaügyi Szervezet (ILO) helye és szerepe a munka világában. 5. fejezet (Rusinné Dr. Fedor Anita) Foglalkoztatáspolitikai stratégiák Európában, 6. fejezet (Rusinné Dr. Fedor Anita) A foglalkoztatáspolitika finanszírozása az Európai Unióban. 7. fejezet (Nemeskéri Zsolt) Foglalkoztatáspolitika Magyarországon.

II. rész. 1. fejezet (Szellő János - Nemeskéri Zsolt) A munkaerőpiac társadalmi, gazdasági meghatározottsága, 2. fejezet (Szellő János) A munkaerőpiac európai sajátosságai, 3. fejezet (Sebők Marianna) Munkaerő-migráció és az európai munkaerőpiac 4. fejezet (Szellő János - Sebők Marianna) A magyarországi munkaerőpiac jellemzői, rendszere, eszközei. Kiegészíti a kötetet a Fogalomtár, válogatott irodalomjegyzék segíti a tovább tájékozódást.

A kötethez Dobák Miklós és Munkácsy Ferenc írtak bevezető gondolatokat. A hazai foglalkoztatáspolitika célja a megfelelő emberi erőforrás technikák és egyéb eszközök megválasztásával a népesség integrációja, a társadalmi kohézió lehető legmagasabb fokának elérése, a termelékenység fenntartása, a versenyképesség növelése érdekében. Ebben és erre, bár az Európai 
Unió számos ajánlást fogalmazott meg, meghatározva például a fejlesztési irányokat és a hosszú távú stratégiai célokat, azonban érvényesülnie szükséges a nemzeti sajátosságoknak. Az uniós törekvésekben számos irány található, pl. az Industrial All Europe egyik folyamatosan hangoztatott törekvése az európai közösségi foglalkoztatáspolitika. A változó körülményeknek megfelelő konkrét intézkedések és eszközök kidolgozása az ország felelőssége. Ehhez átfogó tudásra van szükség, amelyhez e kötet új megközelítésben ad támogatást. 